\title{
7. The Importance of Being Coral Bell ${ }^{1}$
}

\author{
JDB Miller
}

Declaring one's interest is often necessary, very much in this case. I have known and admired Coral Bell for fifty years, ever since she and I were tutoring students in International Relations at the London School of Economics (LSE). She has since become the most respected and prolific of Australians in this field, and remains an acute analyst of what happens in the world, especially in terms of conflict and alliances.

Having graduated from the University of Sydney, she entered the Australian Diplomatic Service. After some time abroad, she evidently decided to enter academic life, and proceeded to the LSE to do postgraduate work. There she came under the influence of Martin Wight and became a colleague of Hedley Bull. Even though I would personally regard it as to some extent a barren time because of the tenure of Professor Charles Manning as Head of Affairs, there was no doubt of the effect of Wight's personality and his awareness of the international system: he was an inspiration to all who knew him. When, years later, he told me that, when asked to recommend someone for the Chair of International Relations at Sussex University, he could only hesitate between two Australians, Coral Bell and Hedley Bull. Coral took the job.

The Sussex Department turned out to be an unhappy place; after some time, Coral thought of returning to Australia. Hedley and I, learning of this, were delighted to lure her to the Department of International Relations in the Research School of Pacific Studies at The Australian National University (ANU), of which we were joint heads. Here she continued her published work, and contributed to both the Department and the Strategic and Defence Studies Centre. She joined Hedley, Robert O'Neill, TB Millar and myself as a Fellow of the Academy of the Social Sciences in Australia. She continues to produce: the ANU Library lists thirty books she has either written (the majority), edited, or contributed to (the smallest category). They cover the world situation, Australian foreign policy, and particularly American policy under a succession of presidents.

The work displays great clarity with an absence of jargon, much practicality and historical sense, and a full awareness of the problems of high-level diplomacy,

\footnotetext{
1 This is a revised version of an article previously published by Taylor \& Francis Ltd., as: JDB Miller, 'The Importance of Being Coral Bell', Australian Journal of International Affairs, vol. 59, no. 3, September 2005, pp. 261-263; and has been reprinted by permission of the publisher.
} 
as, for example, in her studies of John Foster Dulles and Henry Kissinger. It is not surprising that she has been widely acknowledged in Britain and the US for the depth and range of her thinking.

Though her numerous books on the international situation are all important, it seems to me that Coral Bell's main interest and considerable achievement lie in the foreign policy of the US, a power which has been dominant (but not always successful) in the international system, and which she knows intimately through personal contact and frequent visits. For the purposes of this treatment I shall concentrate on a single article, hoping to indicate her methods and her insight into how the US goes about its activities, and why. The article is 'American Policy in the Third World'. ${ }^{2}$

Bell makes it clear that the US is an 'intensely plural society' - a matter not sufficiently recognised in much Australian discussion of the country, which tends to concentrate on the east and west coasts and ignores the mid-west and south and the social make-up. She discerns two earlier strands in US policy towards the Caribbean and Latin America, those identified with Theodore Roosevelt's aggressive 'backyard' policy, in which the US pushed the Monroe Doctrine to extremes, and the 'good neighbour' policy of Franklin Roosevelt, which, along with private efforts, emphasised humanitarian and friendly connections with the often unruly neighbours to the south.

Her point in recalling this history is that these two traditions persist: even in such apparently belligerent regimes as those of Richard Nixon and Ronald Reagan, one can see both strands at work. She sees them extend in later years, including the present, from the western hemisphere to the Third World at large - though she does not accept the notion that there is a unified Third World: it is individual Third World countries, especially in the Middle East, that she has in mind.

Out of this matrix of earlier and recent themes she sees two approaches to US foreign policy. On the one hand,

American official spokesmen ... desire and promote change (in the 'right' direction, admittedly), citing the official Wilsonian progressive notions of human rights and national self-determination, and making a case for linking these political desiderata to economic policies allowing reasonable play to the forces of the market.

Bell sees these attitudes as having been largely dominant in recent times, but with an underlay of attitudes of the second strand, preserved in the bureaucracy,

2 See Coral Bell, 'American Policy in the Third World' in Robert O'Neill and RJ Vincent, (eds), The West and the Third World, Macmillan, London, 1990, pp. 51-66. 
and reflected in the fact that US public opinion, especially liberal-democratic opinion, maintained an authentic humanitarian concern for the welfare of Third World peoples in general, and that strand of public feeling was quite articulate, and also quite able to bring pressure to bear on Washington policy-makers, even in the days of the 'Reagan Doctrine', as witness Congressional recalcitrance on Nicaragua.

She sees 'a large gap between operational and declaratory policies, what the President [Reagan] did and what he said.' Perhaps it will be the same with all administrations, the two strands/traditions coinciding and clashing in varying degrees. Bell sums it up:

The Reagan Administration's decision-making process (if that is not too charitable a term) seems even more dispersed and incoherent than has been the case for most American administrations. And nowhere was that more true than on Third World issues. Thus the inherent pluralism of American society was often expressed in what seemed a confused and confusing multiplicity of attitudes and policies.

Of course, much has changed since 11 September 2001 and the re-election of President George W Bush. Yet Bell's analysis, based on history and shrewd and penetrating as it is, remains a reliable guide to much of how American policy proceeds. There is much more to ponder in the realism of her other writings: she has brought a practical and sophisticated analysis to the study of the international system and Australia's reaction to it. She continues to do so. That is the importance of Coral Bell. 
This text taken from Power and International Relations:

Essays in honour of Coral Bell, edited by Desmond Ball and Sheryn Lee, published 2014 by ANU Press, The Australian National University, Canberra, Australia. 